\title{
Telangium Scotti, a new Species of Telangium (Calymmatotheca) showing Structure.
}

\author{
BY \\ Miss M. Benson, D.Sc., \\ Senior Lecturer in Botany at the Royal Holloway College, Englefield Green. \\ With Plate $\mathrm{XI}$ and a Figure in the Tert.
}

\begin{abstract}
MONG the numerous plant remains preserved for us as impressions $A$ on the Palaeozoic rocks are some digitate clusters attached to branching petioles devoid of lamina, and associated with, and sometimes attached to, leaves of the Sphenopteris type.

They were first investigated and named by Dr. Stur ${ }^{1}$. The species Calymmatotheca Stangeri, Stur, may be taken as the type of these impressions. Dr. Stur regarded the constituent parts of the cluster as indusial valves, but they were differently interpreted by Renault, who figured them in his 'Cours Fossile' 2 as sporangia.

M. Zeiller ${ }^{\mathrm{a}}$ also supported the sporangial interpretation of the lobes. Several species of genuine sporangia have subsequently been included in the genus Calymmatotheca, e.g. C. affinis and $C$. asteroides. They were all founded on casts, however, and it was not until May, 1902, that petrifactions were obtained. Sections of coal nodules from the Gannister beds of Dulesgate and Hough/Hill have recently been yielding a good many of these synangia, some of which have been beautifully cut in series by Mr. Lomax of Bolton.

This led to a re-investigation ${ }^{4}$ of Stur's type-specimens, which has convinced me that he was right in his interpretation of his specimens, and that

1 Die Culm-Flora, $1875-77$.

Cours d. Botan. Foss, troisieme année, p. 198,1883 .

- Bassin houiller de Valenciennes. Flore Fossile, 1888, p. 34 Sar quelques Fougetres honilleres d'Asie Mineare. Bull. Soc. Bot. de France, tom. xliv, p. 199.

- Dr. Scott and Prof. Oliver tell me they have come to the same conclasion after a careful -inspection of the specimens. The re-investigation was rendered possible by the kindness of the Director of the Geol. Reichsanstalt at Vienna, who, at the request of Dr. A. Smith Woodward, F.R.S., lent the valuable specimens in question to the Geological Department of the British Mureum, so as to give English Palaeobotanists an opportanity of examining them.
\end{abstract}

[Annele of Botany, VoL XVII. No. LXIX. January, 1904.] 
no sporangia can therefore be included in the genus Calymmatotheca, which he founded upon $C$. Stangeri, $C$. Haueri, $C$. Schimperi, and $C$. minor. I have founded therefore the form-genus Telangium for the reception of such specimens as can be diagnosed as follows :-Fertile and barren pinnae dissimilar ; fertile pinnae represented by synangia only; synangia borne at the extremity of the ultimate ramifications of rachis, composed of 6-12 sporangia which taper to the apex and are united primarily for almost their whole length to form a body which is continued into a sterile base of decreasing diameter through which runs longitudinally a single vascular strand. Each sporange ultimately becomes almost free from the others by septicidal dehiscence and liberates large spores from a ventral suture. As I have not been able to identify these new specimens with any so far described species, I have much pleasure in calling it Telangium Scotti, after Dr. D. H. Scott, F.R.S., whose work on Lyginodendron has added to the interest in this type of fructification.

The first specimen that came into my hands was the longitudinal, tangential section represented in Pl. XI, Fig. T.

The longitudinal dimensions of the sporange on the left are $3.2 \mathrm{~mm}$., but the full length of the sporange was probably somewhat greater. If one compares Fig. 8 one sees that the sporange has really a free narrow apex which brings its length up to $3.8 \mathrm{~mm}$.

The sterile base would probably have brought the length of the whole synangium up to at least $5 \mathrm{~mm}$.

The width of the eynangium averages a little under $3 \mathrm{~mm}$. before dehiscence, if it be measured at the widest part.

Shortly after examining this preparation I was enable by the kindness of Prof. F. W. Oliver to look through slides from a similar source that belonged to the Collection at University College, London. These yielded a beautiful series of four slides (C.N. $\mathrm{K}_{3} a-d$ ), cut from a block containing three synangia, and Figs. 2 and 3 have been drawn from them. Mr. Lomax has recently cut another excellent series, which is now in Dr. Scott's Collection, and has been kindly lent to me with other slides for the purposes of this paper.

One slide from the Manchester Collection, which I owe to the kindness of Prof. Weiss, has also been of service and is shown in Fig. 9.

It will be seen from the drawings that the synangium has eight sporangial chambers arranged in two rows. If we take the transverse sections in the order of their position, beginning at the base, we should first examine Fig. $4 \mathrm{~A}$, which is a transverse section of a synangium immediately below the insertion of the sporangia.

The long diameter of the ellipse is $1.7 \mathrm{~mm}$., and the short diameter is $9 \mathrm{~mm}$. in length.

This section shows the vascular bundle in transverse section, the 
outline of which is not very clearly defined, but can be seen to contain tracheides of narrow lumen, $v$. Fig. $4 \mathrm{C}$. These are best seen rather to one side of the section, and possibly occupy one arm of a $\mathbf{V}$-shaped strand.

The whole section is limited by the large-celled epidermis with blackened contents; within this are groups of thin-walled cells which have broken down, and at $l$ the section has passed through the lacunar tissue, which is visible again in Fig. 2 and partially in Fig. 1.

Fig. 2 represents a section of another synangium at a level just above that of Fig. $4 \mathrm{~A}$. We see that the dimensions have much increased. Two of the sporangia have been injured. The walls are thicker than they are nearer the apex, and show at least seven layers of cells. The epidermis is supported by a hypoderm which is not so regular as is the case at a higher level. The lacunar tissue appears at $l$ and $l_{1}$. I have been unable to trace any vascular strand at this level-

Fig. $4 \mathrm{~B}$ is a section at a slightly higher level. The septa have given way at two places which probably represent the basal parts of the fissures shown in Fig. $5 \mathrm{~B}$, which is another section of the same synangium. Fig. $4 \mathrm{~B}$ shows the hypoderm to consist at this. level of an interrupted layer of cells empty of contents. In - many. cases they show scalariform marking. This can be best seen in Figs. I and 2. They are elongated in the long dimension of the sporange, and are probably not continuous with the vascular strand but simply hypodermal cells differentiated for some special function. It is of course possible they were of use at first as waterconducting elements, but it seems more probable that their chief function was to secure dehiscence. They may be regarded as physiologically analogous with the fibrous layer in the wall of the pollen-sac of Angiosperms. If we refer to Fig. $5 h h^{\prime}$. we shall see that on the outer wall between each sporange there is a group of thin-walled cells which tear on dehiscence. This would be brought about by the contraction of the convex, free portion of the sporangial wall. This contraction may very well have been due to the hygroscopic structure of the membrane of these hypodermal cells.

At intervals the living parenchyma interrupts these. cells. This may be seen well in Fig. 3 and in $5 \mathrm{~A}$, at $x$ and $x^{1}$, and it is possible that contraction may have been aided by loss of turgidity in these cells.

The sections taken at a higher level where the sporangia have separated from one another are represented in Figs. $3,5 \mathrm{~B}, 7 \mathrm{~B}$, and 9 . It is easily seen that part of the wall of each sporangium is composed of a segment of the peripheral wall and a thinner part derived from the partition which splits longitudinally, reminding one of the septicidal dehiscence of a syncarpous fruit. There is, however, one exception to this, for the epidermis is complete all round the extreme apices which appear to be free primarily, 
v. Fig. 5 B, $e p$. This should be compared with Fig. $8, e p$., where the free apex may be seen still containing spores.

The spores seem to have been ripe, and in most cases have been partially shed. In one sporange in Slide C.N. . M . 2 I (a) from Sharney Ford, kindly lent me by Prof. Oliver, there are numerous spores. Fig. $6, a, b, c, d$, are drawings of such spores made with the help of Zeiss's Abbe Camera, and show the form and characteristic wall of the spore. The spores vary slightly in size and form. Many are somewhat elliptical, measuring from 5 to $6 \mu$ in the longer dimension, and from 4 to $3.5 \mu$ in the shorter. Many look circular, but this may of course be due to the elliptical forms being looked at end-on. They are reticulately marked, the ridges meeting at an angle of about $120^{\circ}$, and the thinner areas are approximately hexagonal.

In form and in the character of the wall these spores agree very closely with the pollen-grains in the pollen-chamber of Lagenostoma ovoides, which

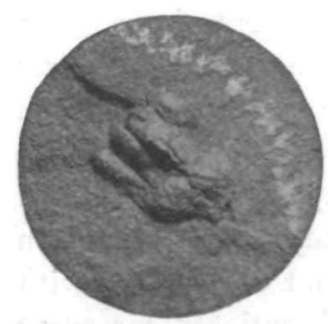

FIG. 33. $\times 4$. are drawn in Fig. 6, e, f,g. The size of the latter is, however, slightly greater. Those in the pollenchamber of a Lagenostoma ovoides in my collection measure 6.75 , and $7.2 \mu$ in the longer dimension and $5 \mu$ in the shorter. An increase in size of a pollen-grain after entering the pollen-chamber is known to occur. In the interesting parallel case recorded by Renault of the pollen-grains of Cordaianthus the shagreen-like coats of the spores were similar, but the size of those in the pollen-chamber showed a marked increase. We are now in a position to construct a diagrammatic figure if we superpose these sections upon one another, and the result is given to scale in Fig. 10. Septicidal dehiscence has advanced almost to the base. of the synangium.

It will be seen how closely this, resembles some of the Calymmatotheca impressions, which are reproduced for comparison (Figs. II and $\mathrm{I}_{2}$ and Text-Fig. 33). Stur's drawings of Calymmatotheca Stangeri (Fig. I1) show a form very similar to that of $C$. Scotti, except that the former is distinctly larger, measuring 6 to $8 \mathrm{~mm}$. in length, whereas $C$. Scotti, even if we take account of the sterile base, can hardly have reached more than $5.5 \mathrm{~mm}$.

But the chief difference is due to the absence of relief in the impression, which in this respect offers a sharp contrast to the form reproduced photographically in Text-Fig. 33. The many specimens of the latter I have seen lead me to wholly agree with Mr. Kidston's interpretation of it as sporangial, and I shall, for convenience, therefore refer to this species as Telangium affine. The same may be said of the other British species which will be referred to under the names Telangium asteroides and T. bifidum. 
Count Solms-Laubach, in a recent review ${ }^{1}$ of my preliminary note to this paper in the Annals of Botany, 1902, stated that the agreement between the new species and $C$. Stangeri is not perfect owing to the absence of thorn-like emergences on the back of the sporangia in the new species. This was in reference to Stur's Plate VIII, figs. 5 and 6, which show emergences on the lobes reminding one of the glands on the newly discovered outer envelope of Lagenostoma Lomaxi; and it is of course possible that this may be shown by Drs. Oliver and Scott to be their nature. This valuable criticism is met by my present action in withdrawing the new synangium altogether from Stur's genus and founding a new one.

In 1877 a paper ${ }^{2}$ by the late $\mathrm{Mr}$. C. W. Peach was read before the Geological Society describing some beautiful casts ${ }^{3}$ of a smaller form of Telangium, hitherto known as C. affinis (see Fig. 12). He found them attached to fronds of Sphenopteris affinis, and suggested that they were parasitic upon them. 'Each flower-like form' (Mr. Peach's expression for the synangium) ' is about $\frac{1}{8}$ in. over and fully that in height.'

Mr. Peach compared his specimen with that of $C$. minor as figured by Dr. Stur, p. 237 of his 'Culm Flora,' and it is not impossible that $C$. minor may be a Telangium.

By the kind permission of the Council of the Geological Society I have been enabled to reproduce two of Mr. Peach's figures (Fig. $12 a$ and $b$ ).

The form of $T$. affine is very like that of $T$. Scotti, but it is distinctly smaller. The dimensions as kindly :given me by $\mathrm{Mr}$. Kidston are as follows :-

Length, $2.5-3.5 \mathrm{~mm}$.

Breadth, 2.75-3, (after dehiscence).

Those of $T$. Scotti are as follows:- .

\section{Length, $4.5-5: 5 \mathrm{~mm}$.}

Breadth, $\cdot 3$

(before dehiscence).

The figure in the text is reproduced from a photograph kindly made expressly for this paper by $\mathrm{Mr}$. Kidston of a specimen of $T$. affine in his possession. It is noticeable that the synangia of $T$. affine are represented sometimes in approximation and in planes parallel to one another (Fig. 1 2a). This seems to have been the case also in $T$. Scotti, as is shown in Figs. 3, 4, and 5. These specimens of $T$. affine were found by Mr. Peach in the Calciferous Sandstone rocks of North Britain, and the two species thus belong to different horizons.

Another British species the description of which we owe to Mr. Kidston 4

Bot. Zeitung, 60, Dec. 1902.

- Quarterly Joumal of the Geol. Soc. of London, vol. xrxiv, p. I31.

- Admirable specimens of these are preserved in the British Museam.

- Trans, of the R. S. Edin., vol. xxxiii, p. 140. 
is T.bifidum. The synangia are still more markedly aggregated than those of T. affine. A careful examination of Mr. Kidston's Figs. I-6, Platę VIII, would lead me to conjecture that the synangium is composed of not more than ten or twelve sporangia, and that the appearance of a greater number is due to the shortness of the ultimate ramifications and hence the almost capitate condition of the fructification. The dimensions of the synangium of $T$. bifidum are given by Mr. Kidston as follow:-

$$
\begin{aligned}
& \text { Length, } 6.5-6.7 \mathrm{~mm} \text {. } \\
& \text { Breadth, 3.75-4 " }
\end{aligned}
$$

Mr. Kidston's Fig. 6.a, Plate VIII, depicts one synangium in which bipartition is very noticeable, and may be compared with Fig. 7, which represents a synangium of $T$. Scotti showing the same tendency. .

We see from this review that, as respects size, $T$. Scotti is intermediate between $T$. affine and $T$. bifidum, and that it shows many features in common with both species. The only species of Telangium recorded so far from the Upper Carboniferous ${ }^{\mathfrak{l}}$ is $T$. asteroides. This is generally represented as having had but six sporangia in its synangium, but I have not been able to confirm this from the specimens preserved in the British Museum. The longitudinal dimension of the synangium is a little over $3 \mathrm{~mm}$. The synangia are borne on branching, petioles like those of other species. Owing perhaps to its imperfect preservation it does not seem to be so near $T$. Scotti, the new Upper Carboniferous form, as do several of the species already referred to, which belong to the Lower Carboniferous.

As the attribution of Telangium Scotti to Lyginodendron was at the time ${ }^{2}$ partly based upon what Dr. Scott and I now consider to be a misihterpretation of Stur's type specimens of Calymmatotheca Stangeri, it remains for me to discuss what evidence is still available in support of the view adopted in the preliminary note ${ }^{2}$ to the present paper.

Not only is internal evidence available owing to the preservation of the tissue of Telangitm Scotti, but the recent announcement ${ }^{3}$ on the part of Messrs. Oliver and Scott that the seed Lagenostoma Lomaxi grows attached to an envelope showing characteristic structural features of Lyginodendron Oldhamizum has given unexpected opportunity for further comparison.

The evidence may now be summarized under the following headings :-

I. Association and character of impressions or casts.

2. Association of petrifactions.

3. Character of tissue.

4. Correspondence between the spores of Telangium Scotti and the

1 Potonie's statement in Engler's Pfanzenfamilien, Teil I, 4. Abteilang, p. 449, that Calymmatotheca belongs to the 'Ober-Carbon' seems due to an error, as he does not refer to $C$. asteroides.

2 Benson, The Fractification of Lyginaderdron (note), Annals of Botany, xvi, 19o2.

- Proc. R. S., vol. Ixxi. 
pollen-grains germinating in the pollen-chamber of Lagenostoma Lomaxi and $L$. ovoides.

5. Correspondence in certain morphological characters between the synangium of Telangium Scotti and the seed Lagenostoma.

We will deal with these subjects in succession, and the last will be found to involve a wholly new theory of the phylogeny of the inner integument.

Firstly, association and character of impressions. Those who have had the pleasure of studying the numerous and beautiful plates the late Dr. Stur included in his 'Culm Flora' and 'Carbon Flora' cannot but be impressed with the family likeness which seems to reign among the fronds, whether they are called Calymmatotheca, Diplothmema, or Sphenopteris. Zeiller has expressed the view that they all belong to stems of the Lyginodendron type. The branching of the leaves may be dichotomous, or pinnate, or various combinations of both systems. These leaves are in one case found associated with one species of Telangium fructification. Thus $T$. minor is found associated with Sphenopteris (Diplothmema) patentissima, and also with indusiate seeds which Stur calls Rhabdocarpus conchaeformis.

Turning to records of British impressions of Telangium we have three- $T$. affine and $T$. bifidum from the Lower Carboniferous, and $T$. asteroides from the Upper, i. e. the Lower Coal Measures.

$T$. affine is not only associated with but attached to leaves of Sphenopteris affinis, so much so, indeed, that $\mathrm{Mr}$. Peach in the description of his beautiful specimens suggests that they were parasitic upon the leaf. The frond in this case, which is familiar to many as represented in the frontispiece of Hugh Miller's ' Testimony of the Rocks,' dichotomizes freely, and thus exhibits a type of branching also found in Sphenopteris elegans, the leaf of Heterangium. T. bifidum is also found growing on leaves very similar in character to those of Sphenopteris affinis, as bifurcation is frequent. There is no reason to expect in such an advanced type as Lyginodendron an exact correspondence in size and form between the microsporophyll and the sterile frond, and with this interpretation of such fronds in view it is interesting to note in this latter British species the appearance of the synangia only on the more basal part of the leaf.

Secondly, the association of the petrifaction $T$. Scotti with Lyginodendron in the coal-nodules of the Gannister beds of Lancashire. Not much weight can be attached to the fact of the association with fragments of Lyginodendron owing to the great abundance of the latter in these nodules. But the value of the association is augmented by the fact that $T$. Scotti appears in sections of a nodule from Sharney Ford which is otherwise almost purely composed of the vegetative organs of Lyginodendron. It may also be stated that in several of the slides containing sections of $T$. Scotti there are also Lagenostoma seeds. Their close approximation 
is shown in one case in Fig. 9, which is from a slide kindly lent by Professor Weiss from the Collection of the Manchester Museum, Owens College.

Thirdly, the character of the tissue. The tissue of the lower part of the synangium has much in common with the familiar sterile pinnae of Lyginodendron. We have a well-developed epidermis, a definite hypoderm, and lacunar tissue which is indistinguishable from the corresponding tissue of the sterile pinna. The vascular strand of the pedicel is composed of tracherdes of very narrow lumen, and thus resembles those of the petiole of Lyginodendron. The preservation of the tissue is unfortunately not good enough to show the form of the strand clearly. The group of tracherdes which is preserved (Fig. 4 C) may be the whole, but it is possible that another corresponding group may have occupied the other arm of a $\mathrm{V}$ shaped strand, but has become opaque owing to the minuteness of the lumen of the tracherdes.

Fourthly, correspondence between the spores of Telangilsm Scotti and the pollen-grains germinating in the pollen-chamber of Lagenostoma Lomaxi and ovoides. Ripe spores occur in five of the synangia already to hand, and have been measured by Prof. Oliver and myself. As already pointed out they agree with considerable exactness in form and in the character of the wall with the pollen-grains in the pollen-chamber of Lagenostoma, but the latter slightly exceed them in size. This comparison, already found of value in the magnificent work of Renault on Cordaianthus, is of great interest. The spores of Telangium average $5.5 \mu$ in their longer and $3.7 \mu$ in their shorter dimension. The spores when they are germinating, apparently in the very act of yielding antherozoids like those of Cycads and Ginkgo, measure $7 \times 5 \mu$. The wall of both is thick and has thinner areolae, and thus may be described as reticulate, $v$. Fig. 6.

Fifthly, correspondence of Telangium Scotti in certain morphological characters with the seed Lagenostoma. The seed Lagenostoma (the three species of which were first named and partially described by Williamson) has since received a searching investigation at the hands of Prof. F. W. Oliver ${ }^{2}$. The connexion of one species, L. Lomaxi, with Lyginodendron has recently been announced ${ }^{2}$ by him and Dr. Scott. To quote from their account of this species: 'In the most general relations of its organization the seed approaches the Gymnosperm type in that the integument and nucellus are distinct from one another in the apical region only, whilst the body of the seed which contains the large single macrospore shows complete fusion' of the integument and nucellar tissues. But in other respects the seed is remarkable. The integument, which is a simple shell where fused with the nucellus, becomes massive and comFig. 9.

'See ' Oliver, The Ovales of the older Gymnosperms,' Annals of Botany, rvii, rgo3, Pl. XXIV.

Proc. R. S., vol. lxxi. 
plicated in its free part which corresponds to the upper fifth of the seed. In this region it is usually composed of nine chambers radially disposed around the micropyle. The whole structure from within is like a fluted dome or canopy, the convexities of which correspond to the chambers: The vascular system of the seed enters as a single supply bundle at the chalazal papilla and branches a little below the base of the macrospore into nine radially-running bundles. Each of these bundles passes without further branching to the apex of the seed, running outside the macrospore and a little distance below the surface. At the canopy the bundles enter the chambers and end at the tips.'

A somewhat lengthy quotation has been made, as it is necessary to understand the structure of the seed if the comparison with the microsporangial sorus is to be appreciated. The transverse section ${ }^{1}$ of the seed, if taken in the plane of the canopy, somewhat resembles a cartwheel, in which the nucellar apex forms the axle, the radial walls between the chambers the spokes, and the peripheral walls of the chambers the rim of the wheel. The comparison does not hold good, however, in well-preserved sections, as the chambers are -seen each to contain large, thin-walled cells which support the delicate branch of the vascular bundle that is contributed to each.

The correspondence which must have already suggested itself to the reader is between such a seed as Lagenostoma and such a synangium as Telangium Scotti. The chambers surrounding the nucellus seem to represent its sister sporangia, which have become sterile, the largecelled, thin-walled tissue and delicate vascular strand being all that represents the ancestral sporogenous tissue,; while the micropyle corresponds with the original space between the tips of the sporangia. The seed in fact is assumed to be a synangium in which all but one of the sporangia are sterile, and form an integument to the one fertile sporange which has become a megasporange with one large megaspore. In Lagenostoma physoides ${ }^{2}$ the integumental ridges are continued into tapering tentacles around the micropyle, and this still further accentuates the resemblance to a sorus. In $L$. ovoides the number of chambers is often seven instead of nine. Hence we have only to imagine that one of the sporangia of a sorus of eight or ten sporangia gradually evolved megaspory, and that the remaining seven or nine sporangia became a sterile envelope,-a correlation in development which has many analogies in the animal and vegetable kingdoms. As soon as one of the sporangia became a megasporange the symmetrical arrangement of the sister sporangia would become an advantage and naturally follow. At the remote period of time at which the seed was

1 Oliver, loc. cit., p. 461.

- See Williemson, Phil. Trans., vol. clrvii, 1877 , Pl. XI, Fig. 77. A fall account by Prof. Oliver of this seed will appear shortly. It should be compared with Telangium biffdum. 
evolved, a period probably anterior to the Carboniferous epoch, it may be conjectured that the arrangement of the sporangia in the sorus was irregular, and that the more centrally placed sporange with its better vascular supply may have gradually attained the megasporangial condition. In Gleichenia and Oligocarpia some sori have, and others have not, a central sporange. As respects the vascular supply in the centre of each compartment of the integument, it is well known that in many of the Permo-Carboniferous seeds a vascular bundle entered the base of the nucellus, even passing from the chalaza to the pollen-chamber ${ }^{1}$, and it is hence easy to conceive of a vascular strand having early entered its sister sporangia. Again, if we take an example from a seed of very remote affinity, we find that in Castanea a vascular strand may be demonstrated running up the whole length of the nucellus, and is especially well developed in nucelli whose embryo-sacs have long remained unfertilized.

I will now proceed to show that this interpretation of the integument of Lagenostoma is helpful in clearing away many of the difficulties that have beset the general problem of the integument hitherto. The more generally accepted interpretation of the inner integument is that it is due to a special development of the indusium. We are compelled to regard the integument of Lagenostoma as a single integument, firstly because of the primitive character of the seed, and secondly because of the existence in $L$. Lomaxi of an exterior envelope. Hence it is probably safe to regard it as homologous with the inner integument, and consequently as hitherto accounted for mefely by Čelakovskýs theory of the indusium, or by another theory to which I will allude later. But the cohesion of integument and nucellus which we know to be'characteristic of the Cycadean seed receives no explanation on the indusial theory, whereas on the synangial theory the cohesion is seen to be due to the origin of the seed from structures already coherent.

- Moreover, as it is generally agreed that the heterosporous habit arose from the homosporous, it is a priori probable that there should be a correspondence between the microsporangial sorus and the primitive seed, and this correspondence seems best obtained by harmonizing the seed and the synangium.

If it should be shown conclusively that $T$. Scotti is the microsporangial organ of Lyginodendron the homologizing of Lagenostoma with its $\delta$ synangium would simplify the problem of the integument in that we should then have but one envelope to account for in the seed over and above what was present in the male sorus.

I will now refer shortly to another widely accepted view, which has been adopted by Strasburger, Treub, and Dr. Lang. Though their views 
vary as to the homologies of the seed as a whole they agree in regarding the integument as a new formation.

Dr. Lang's conclusions are based on his own investigation into the morphology of the sporangia of Stangeria ${ }^{1}$, and on the results of work by Warming and Treub on other genera of Cycadaceae. He points out that ' with regard to the development considerable correspondence between the ovule and the sorus can be traced in the early stages. The differences between the development of the sorus of microsporangia and the ovule only become pronounced when active growth becomes localized around each archesporial group ?' He therefore homologizes the sorus and the ovule at the outset, but looks upon the ovular sorus as monosporangiate and the integument 'as an annular upgrowth, around the apex of the nucellus, of the bulky sporangial wall or, which comes to the same thing, of the edge of the receptacle which had kept pace with the single sporangium.'

Thus it would appear that owing to the relatively advanced type of seed investigated, Dr. Lang could not homologize the upgrowing 'edge' of the receptacle with sterilized sister-sporangia of the nucellus. He adds that his view is only put forward as a provisional statement, which will have to be tested 'in the light of the evidence obtainable from. extinct forms.' It is in the light of these extinct forms that the new theory of the integument is now being put forward.

Whether $T$. Scotti be ultimately proved to belong to Lyginodendron or not, we may well bear in mind that the synangium is a very ancient type of fern fructification, for from the Culm onwards we have numerous examples of it recorded. Where the individual sporangia are not entirely coherent they generally form a sorus of bulky sporangia like those of the Filicinean class 'Simplices' suggested by Professor Bower. The ancient sporange was very rarely solitary, and we have already undoubted evidence in Cycadeoidea of a seed-plant having synangia for its microsporangial organ.

Among synangia which are found associated with Cycadofilicinean seeds are Hawlea and Scolecopteris ${ }^{8}$. The latter I will shortly describe, as I believe a reference to it may make the comparison of seed and synangium more clear.

Scolecopteris is a form-genus including several species of sorus, which have been described by a succession of palaeobotanists ${ }^{4}$. It is sufficient

' Lang, Annals of Botany, xiv, igoo.

- Note the support that these observations give to the soral theory of the seed.

- Kidston, 'On the Fossil Flora of the Radstock Series of the Somerset and Bristol Coalfield.' Trans. R. S. Edin,, 1888. Also, ' On the Fructification of Carboniferons Ferns,' Trans. Geol. Soc. Glasgow, vol. ix, 1889, Plates II and III. Further announcements bearing on this subject will shortly be made by Mr. Kidston.

'Strasburger, ' Scolecopteris elegans, Zenk.,' Jenner Zeitschrift für Naturw., vol. viii, 1874 
for our purpose to refer to the drawings of Scolecopteris polymorpha in Engler and Prantl, Teil I, Abt. 4, p. 440. It will be seen that the sorus as a whole somewhat resembles $T$. Scotti, but the four or five sporangia, which here constitute the sorus, are inserted around a pedicel along which runs a vascular strand. If this were to become continuous with a strand of tracherdes developed in the sporogenous tissue, we should obtain the vascular supply which characterizes Lagenostoma.

The beautiful plates in Brongniart's 'Recherches sur les graines fossiles silicifiées' afford many opportunities of applying and testing the new theory, and amongst others I would suggest a reference to the following :-

Plate IX, Fig. 4, showing a vascular bundle entering the nucellus in Rhabdocarpus subtunicatus.

Plate XIII, Figs. 6, 7, 17, 19, showing the contrasted tissue-systems of the integument of Sarcotaxus avellana and its septicidal dehiscence.

Plate IV, Figs. I and 3, showing the sporangial appearance of the inner integument continued to the base of the nucellus in Cyclocarpus nummularis. (These figures should be compared with Telangium Scotti, Fig. 8.)

Plate C, Fig. 9, in which the seed Codonospermum is shown to present a striking external resemblance to such a synangium as Asterotheca.

The similarity of the inner integument of Pachytesta to that of Lagenostoma has been recently pointed out by Professor Oliver ${ }^{1}$, and a transverse section has been constructed which exhibits its compartmental nature at a level much lower than that in which it can be demonstrated in Lagenostoma. Professor Oliver adds: "The presence of vascular strands in the chambers of Lagenostoma is the most important difference.'

Much fuller details are to hand of another seed which seems to bear out this theory. I refer to Bennettites Morierei, Sap. and Mar. (spec.), which has been admirably worked out by Professor Lignier ${ }^{2}$. This fructification, as is well known, belongs to a much later horizon, i.e. Mesozoic, and shows Cycadean affinities.

If one consults Lignier's Plate III, Figs. 35 and 37 , one sees transverse sections of the upper part of the seed, showing the thick integument divided up into four compartments by radiating vertical walls of flattened cells, very comparable to those which separate the constituent members of a synangium.

The interior of each compartment is described as succulent tissue, but offers an abrupt contrast to the walls. Plate III, Fig. $3^{8}$, shows

'Oliver, ' On 'some Points of apparent Resemblance in certain Fossil and recent Gymnospermons Seeds.' New Phytologist, vol. i, p. 150, Text-figare 5.

' O. Lignier, 'Structare et Affinités du Bennetlites Morierci, Sap. and Mar. (sp.).' Vtgltanx forsiles de Nomandie. Caen, 1894 . 
the constitution of the integument at a lower level. Here we find the peripheral epidermis of the integument lined as in Telangium and other synangia, with a layer of reticulately thickened cells within which lie the large thin-walled cells which seem to correspond with the sporogenous tissue, and this is limited internally by thick-walled fibres. Plate IV, Fig. 45, shows also on a smaller scale the compartmental structure of the integument.

It is interesting to note that Bennettites Morierei is in some respects evidently less reduced than Bennettites Gibsonianus, in which, as Dr. Scott says in his 'Studies,' the structure of the pericarp is a matter of inference. Nor is there any possibility of avoiding the conclusion that the inner tube of the micropyle is nucellar in origin if we accept the diagrams Prof. Lignier gives.

I cannot but regard this example as very strongly confirmatory of the homology of the seed with the synangium. If we compare the peripheral epidermis of the integument with that of the microsporangial sorus of Cycadeoidea we obtain a possible explanation of the radially elongated epidermal cells ${ }^{1}$ of the sunken seed. Is it possible to call in here the aid of a wholly hypothetical indusium and invest it in turn with so many points of similarity to the sister sporangia of the nucellus, sporangia which it cannot but be granted originally surrounded the ancestor of the megasporange? Or, on the other hand, can we, with others, call in a 'new formation ' to account for an integument so obviously compartmental?

Thirdly, I wish to refer to the seeds which somewhat unfortunately go by the name of Gnetopsis elliptica ${ }^{2}$, Ren.

Although they are not yet worked out with the same detail as Lagenostoma and Bennettites-Morierei there is considerable internal evidence in support of their synangial origin.

They are figured (after Saporta and Marion) in the English edition of Solms-Laubach's Fossil Botany on page 128 , and come from the Upper Coal Measures of Grand' Croix. The ovules occur in one or more pairs in the hollow of a cup-like envelope which bears long hairs.

For convenience I will quote from Solms-Laubach's description of this most interesting type: 'That portion of the integument which encloses the apex of the nucellus behaves in a very peculiar manner, and may be compared perhaps with Lagenostoma, Will. It attains a considerable thickness and separates (sic) into a compact outer lamina and a similar inner lamina, while the cell-layer between the two is formed of extended filaments which represent so many cells and traverse a broad intercellular space at some distance from each other. This looser tissue ceases of course at the micropylar canal, where the outer and inner layer are in connexion with one

1 Cf. Figs 99, Io1, and 102 in Coulter and Chamberlain's 'Gymnosperms.'

- Renanlt, 'Cours de Bot. Fossile,' T. 4, p. 179, Plates 20-22. 
another. The margin also of the orifice of the micropyle is formed of a cup-shaped expansion which is seen to be drawn out at two points into long filiform appendages. A vascular bundle enters at the base of the ovule and splits into four branches.' If this account were translated into the language of this new theory we should say that each of the four abortive integumental sporangia contains loose elongated cells in its upper part, and that their extreme apices are prolonged much as in Lag. physoides, only that they remain adherent in pairs. The other two species of Gnetopsis, G. trigona and G. hexagona, are known only as impressions, and show four or five tentacles around the apex ${ }^{\mathrm{I}}$.

If it should be contended that in the case of Lagenostoma and Gnetopsis this special development of the inner integument is merely of biological significance, I would point out that it is difficult to see then why this should also occur in a seed outtopped by interseminal bracts as e.g. Bennettites Morierei. Nor does this explain the form of the section of the seed-triangular, hexagonal, \&c.-nor the radiating vertical walls dividing the integument into compartments.

If, however; such internal evidence as I have brought forward appears inconclusive, it is satisfactory to find that there is a record in the literature of an exactly comparable-transformation occurring in the sorus of a very ancient monostelic fern stock.

I refer to the fact that Renault in his Autun Flora describes a specimen of Botryopteris sporangia in which a group was found to be surrounded by an envelope formed of sterile and highly modified sporangia ${ }^{2}$. Renault figures some of these sterile sporangia in his 'Flore fossile d'Autun et d'Epinac.'

When we consider that on anatomical grounds it has long seemed probable that the Cycadofilices arose from some ancestral Filicinean group such as the Botryopterideae, we see that such a case as Renault cites is peculiarly significant in any discussion as to the phylogenetic origin of the integument of the seed. Hence any further confirmation of Renault's observation would lend a strong support to the new theory.

I will now refer to a few analogous cases which lend a general support to the claim for the sterilization of certain sporangia in a sorus during the evolution of the Seed.

In Azolla I believe most morphologists would admit that the microsporangial and megasporangial sori were originally similar, and that the megasporangial. has gradually lost by abortion a number of sporangia, retaining only one. If the development of the megasporange in Asolla involved the total loss of its free sister sporangia, are we claiming too much

1 Zeiller, Eléments de Paléobotanique, p. 224

- Renault, Bassin honiller d'Aatun et d'Épinac. Flore Fossile, ii, p. 54. 
if we conjecture that in another Fern the sister sporangia, which were already adherent, were retained as a sterile envelope?

Turning to the Angiosperms, the modification and abortion of flowers in an inflorescence to construct the biologically interesting 'flag apparatus' is exceedingly common. The peripheral flowers in the capitulum of the Cynareae, in the thyrsus of Viburnum Opulus and Hydrangea, are among the most familiar examples. In Muscari comosum (var. racemosissimum) a very remarkable modification follows the sterilization of the central flowers. In Rhus cotinus De Candolle noted an increased growth of trichomes on the pedicels of the sterile flowers, and it has hence become a classical example of what he meant by the expression ' correlation of growth.'

Passing from flower to sporophyll we have no need to mention any of the innumerable instances of the change from stamen to sheathing organ which occurs commonly in Ranunculaceae, Scitamineae, \&c. In Salvia we find that half the anther is sterilized to provide the lever which is to assist in the process of cross-fertilization. If a part of a sporophyll can be sterilized and adapted for an accessory function, why should not some members of a synangium?

- Summary of evidence in support of the view that a seed is a synangium in which the peripheral sporangia are sterilized and specialized as an inner integument:-

.I. Ontogeny. It is shown that wholly independent testimony is borne to the fact that in the most primitive of existing Spermophyta, the Cycadaceae, a correspondence obtains both in position and-development between the microsporangial sorus and the seed.

2. Phylogeny. General considerations would lead us to expect comparable characters in the microsporangial sorus and the primitive seed. A synangium is the only form of microsporangial sorus so far known among the Cycadofilices, and it is found also in Cycadeoidea.

A special case is cited of sterilized sporangia in the tufted sori of Botryopteris.

3. Suggestions of sporangial origin in the inner integument of primitive seeds :-

I. It is frequently compartmental.

2. Each compartment contains large thin-walled cells as contrasted with the firmer peripheral layers.

3. The peripheral wall is constructed of the same characteristic layers as are met with in many synangia.

4. The form of the base and apex of each compartment is often very similar to those of members of a synangium.

5. In some cases there is considerable freedom between the constituent compartments whose apices form the so-called tentacles around the micropyle. 
I 76 Benson.-Telangium Scotti, a new Species of

6. The compartments are comparable in size with the nucellus.

7. The compartments vary in number in the same way as the members of many Palaeozoic synangia.

8. The integument of many of the seeds undergoes septicidal dehiscence like a synangium.

9. The integument is generally as concrescent: with the nucellus as the members of a synangium are with one another.

In conclusion, I may add that though I' regard the theory as of widereaching importance, I am only concerned at present to put it forward as probably the true interpretation of the canopy of Lagenostoma, and hence as adding support to the view that Telangium Scotti is the microsporangial sorus of Lyginodendron: The full exposition of the seed which we await from Prof. Oliver will be based on wider researches into primitive types and a more intimate acquaintance with the difficulties of the problem.

I cannot conclude without expressing my indebtedness to Dr. Scott and Prof. F. W. Oliver. The stimulus of their example and criticism . and their kindness in lending valuable slides have been most helpful. 


\title{
EXPLANATION OF THE FIGURES IN PLATE XI.
}

\author{
Illustrating Misg Benson's paper on Telangium.
}

Telangium Scatti, figs I-10 includve. sporangir.

$h, h^{\prime}$ a groups of cells (which tear on dehiscence), as seen in transverse section between the

$l, l$ - laconar tissue.

s, $s^{\prime}$ - fusiform empty cells with scalarform marking, which form the hypoderm or fibrous layer.

$x, x^{\prime}$ a parenchyma cells interrupting here and there the otherwise uniform fibrous layer.

$\not p=$ free apex.

Fig. I. Longitudinal, somewhat tangential section of the synangium. $\times 33$. A few spores can be seen in the sporange on the left. Slide M.B. Coll. 7I.

Fig. 2. Transverse section of the synangiam but little above the insertion of the sporangla. Two of the latter are injured. The fibrous layer does not extend over the whole surface at this level. Slide lent by Professor Oliver. U.C.L. Coll. $\mathrm{K}_{3}(b)$.

Fig. 3. Transverse sections of tro synangit at a higher level $\times 5^{\circ}$. The fbrous lager is now complete. The group of cells $(h)$ remain undehisced. This preparation also shows the extension of the parenchyma to the surface at $x$ and $x^{\prime}$. Slide lent by Professor Oliver. U.C.L. Coll. $\mathrm{K}_{3}(d)$.

Fig. 4. $A$ and $B$ are transperne sections of two nearly approrimating synangta which are taken at different levels. $\times 33$.

Fig. $4 . A$ is taken below the level of insertion of the sporangia and showa a vascular strand $v$, composed of very mall elements. These are reproduced in a larger scale in Fig. 4 C. $\times 50$. Slide lent by Dr. Scott, C.N. 1803 .

Fig. 5. $A$ and $B$ are transverse sections of the same two synangia represented in Fig. $4 A$ and $B$, bat at a higher level. Some of the spores are well preserved. Slide lent by Dr. Scott, C.N. 1804 .

Fig. 6. Spores $\times 260$. Fig. 6, $a, b, c, d$, are taken from the sections of Scotti, and fig. 6, $e, f, g$, are taken from the pollen-grains in the pollen-chamber of Lagenostoma ovoides. In $a$ and $g \mathrm{can}$ be well the reticalation of the coat. U.C.L. Coll. M 2 I (a); also M.B. Coll. 62, 63, 70.

Fig. 7. $x$ 1a. Transverse sections at different levels taken from a Hough Hill specimen. The dotted lines are merely intended to suggest the relation of the sections. M.B. Coll. $74 a, 74 b$.

Fig. 8. This is an admirable longitudinal section of a portion of a synanginm showing apex and base of one sporangium. $\times 33$. M.B. Coll. 70 .

Fig. 9. A trangveree section through Telangium Scati and Lagenostoma Lomari to show their close association as petrifactions. $c=$ canopy. $n$ a nucellus. Slide 603 , from the Collection of the Manchester Museum, Owens College.

Fig. 10. Diagram constructed by superposing the different transverse sections. $\times 4$.

Fig. Ir. Calymmatotheca Stangeri (natural size), showing three terminal clusten and thorn-like emergences. o c emergences (after Stur).

Fig. 1 . Telangiwm affirs. $\times 4$ (after Peach). a, shows a pair of syangia growing closely adpressed in parallel planes. $b$, a gingle synangium.

Fig. I 2 a, explaios the relative position of pedicel and synangium in Fig. 4. 
Downloaded from https://academic.oup.com/aob/article-abstract/os-18/1/161/195655 by Durham University user

on 27 March 2018 


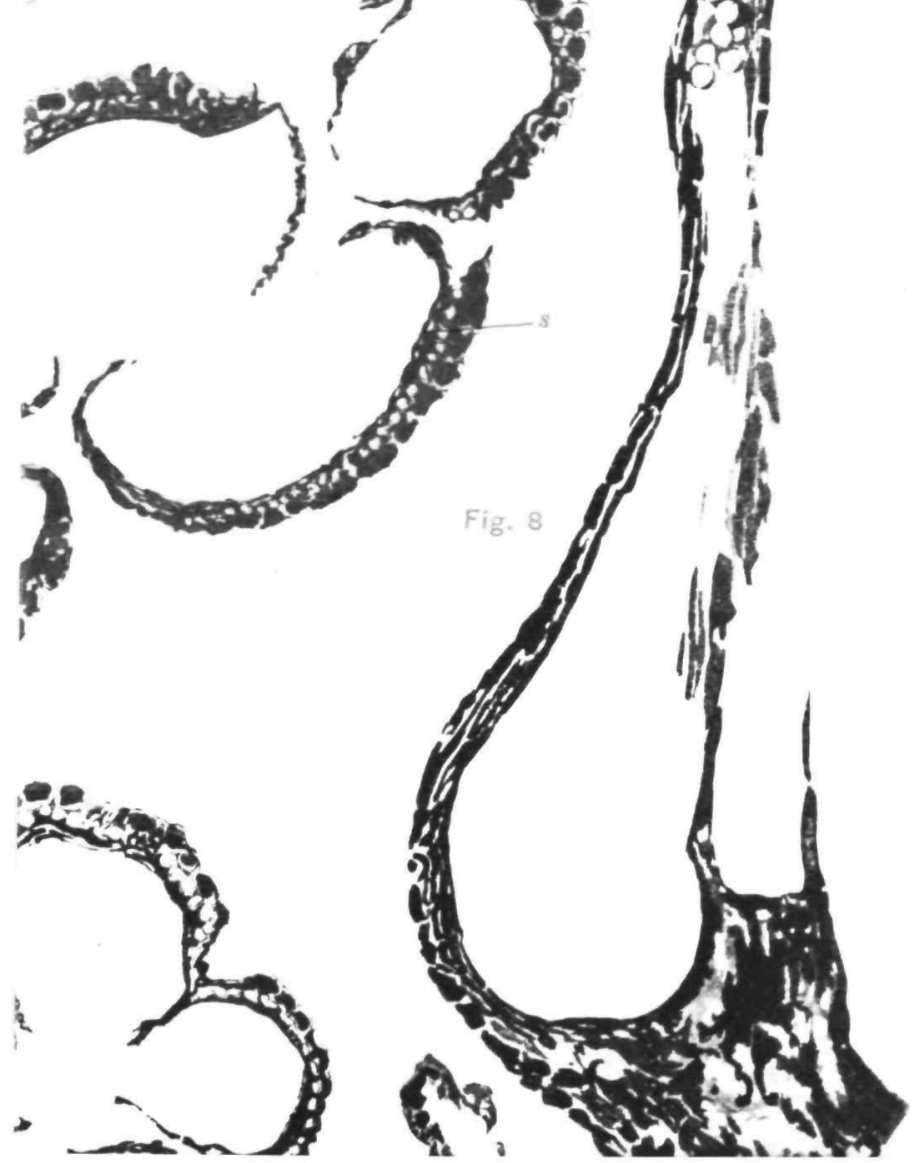


